\title{
MORINGA OLEIVERA TEST AS A NATURAL PRESERVE OF BROILER CHICKEN FILLET MEAT (Gallus domesticus)
}

Dita Nur Kusumawati, Rusmiati, Narwati

\section{ABSTRAK}

Daging ayam memiliki kandungan protein yang tinggi sehingga cepat mengalami proses pembusukan. Upaya menghambat proses pembusukan pada daging dapat menggunakan bahan alami seperti daun kelor yang memiliki kandungan steroid, saponin, alkaloid, flavonoid dan terpenoid sebagai senyawa antimikroba. Tujuan penelitian ini untuk mengetahui pengaruh daun kelor (Moringa olievera) sebagai pengawet alami terhadap angka kuman fillet daging ayam (Gallus domesticus).

Penelitian ini menggunakan desain Post Test Only Control Group Design dengan variasi konsentrasi pembeda dalam penggunaan ekstrak daun kelor yaitu $0 \%, 25 \%, 50 \%$, dan $75 \%$ serta waktu perendaman yang digunakan 30 menit dan penyimpanan 6 jam. Kualitas fisik fillet daging ayam dilakukan secara organoleptik dengan uji sensori dan kualitas mikrobiologi dilakukan uji angka lempeng total.

Hasil penelitian menunjukkan bahwa uji sensori fillet daging ayam setelah penyimpanan variasi konsentrasi memperoleh nilai rata-rata 4 (0\%), 7 (25\%), 7 (50\%) dan $8(75 \%)$ dengan jumlah angka lempeng total rata-rata memperoleh 3,6 x $10^{6}$ koloni/gram,

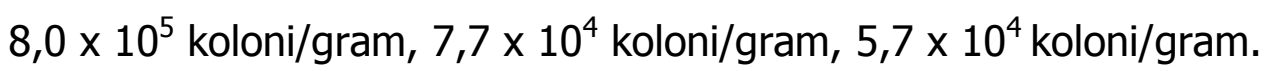

Disimpulkan bahwa terdapat perbedaan antara kosentrasi ekstrak daun kelor dengan hasil angka lempeng total terhadap fillet daging ayam setelah perendaman 6 jam. Bagi masyarakat disarankan untuk lebih memanfaatkan daun kelor dikehidupan sehari-hari. Kata Kunci : Fillet Daging Ayam Broiler, Daun Kelor, Pengawet Alami.
\end{abstract}

\section{A. Pendahuluan}

Daging ayam merupakan hasil produk dari peternakan yang digemari oleh masyarakat. Harga yang ekonomis serta memiliki kandungan nutrisi tinggi, dan tekstur yang lunak, sehingga disukai hampir semua orang. Disisi lain daging ayam merupakan sumber protein hewani berkualitas tinggi karena mengandung asam amino esensial yang lengkap, lemak, vitamin dan mineral yang sangat dibutuhkan tubuh (Risnajati, 2010:Parkhurst dan Mountey, 1988).

Daging ayam yang beredar di pasaran rata-rata berjenis ayam kampung, ayam petelur, dan ayam pedaging (broiler). 
Tingginya permintaan konsumen untuk mengkonsumsi daging broiler dibandingkan dengan daging ayam kampung dikarenakan daging broiler memiliki ciri tekstur daging yang lebih empuk, bernilai ekonomis, mudah ditemukan di pasaran dan ketika dimasak lebih cepat matang ( Dewi dan Diah, 2014).

Rachmita Dewi (2016) menjelaskan dalam penelitiannya bahwa marinasi merupakan salah satu metode pengawetan pada daging dengan proses perendaman menggunakan bahan marinade. salah satu bahan yang dapat digunakan sebagai marinade adalah daun kelor (Moringa oleifera).

Tanaman kelor merupakan salah satu jenis tanaman yang termasuk dalam famillia Moringaceae yang memiliki nilai ekonomis di daerah tropis dan subtropis (Ayotunde dkk ,2011) dan Berdasarkan penelitian yang dilakukan oleh Imy Suci dan Evy (2015) dengan judul kandungan fitokimia beberapa jenis tumbuhan lokal yang sering dimanfaatkan sebagai bahan baku obat di Pulau Lombok memiliki hasil bahwa dalam daun kelor mengandung senyawa metabolit sekunder diantaranya flavonoid, alkaloid, steroid, tanin, saponin, antrakuinon dan terpenoid yang memiliki sifat sebagai antibakteri. Berdasarkan latar belakang yang telah diuraikan diatas, maka penelitian bertujuan untuk menganalisis hasil uji coba daun kelor (Moringa Oleivera) sebagai pengawet alami fillet daging ayam broiler Broiler (Gallus domesticus).

\section{B. Metode Penelitian}

Penelitian ini merupakan penelitian eksperimen dengan desain penelitian True Experimen dengan bentuk Post Test Only Control Group Design, dengan syarat terdapat kontrol, replikasi, dan sampel dipilih secara random. Sampel yang digunakan pada bagian dada dengan berat ayam yang digunakan 100 gram dengan ketebalan $1,5 \mathrm{~cm}$ berbentuk persigi panjang dengan ukuran $2 \times 6 \mathrm{~cm}$. Fillet daging ayam yang diambil di tempat pemotongan ayam di pasar Bangil. Daun kelor yang digunakan untuk ekstrak daun kelor bagian daun kelor umur muda dengan variansi konsentrasi $0 \%, 25 \%$, $50 \%, 75 \%$ dan direndam selama 6 jam.

Untuk mengetahui perbedaan konsentrasi ekstrak daun kelor yang digunakan dengan hasil angka lempeng total digunakan metode metode analisis Uji Anova. Uji lanjutan (Post Hoc Test) kemudian dilakukan untuk mengetahui kelompok mana saja yang berbeda atau yang memiliki pengaruh paling signifikan. 


\section{Hasil dan Pembahasan}

1. Sifat Sensori Fillet Daging Ayam Broiler Sesudah Perendaman 6 jam.

Dilakukan uji sensori bertujuan untuk mengetahui kualitas fisik fillet daging ayam setelah perendaman dengan ekstrak daun kelor berbagai konsentrasi selama 6 jam dintukkan pada tabel V.1 sebagai berikut :

Tabel V.1

HASIL PENILAIAN SIFAT SENSORI FILLETDAGING AYAM BROILER SESUDAH PERENDAMAN 6 JAM

\begin{tabular}{|c|c|c|c|c|}
\hline Konsentrasi & Parameter & $\begin{array}{c}\text { Nilai } \\
\text { Rata- } \\
\text { Rata }\end{array}$ & $\begin{array}{c}\text { Nilai Akhir } \\
\text { Organoleptik }\end{array}$ & $\begin{array}{c}\text { Persyaratan } \\
\text { Nilai } \\
\text { Minimum }\end{array}$ \\
\hline $0 \%$ & Kenampakan & 4 & \multirow{3}{*}{4} & \multirow{3}{*}{7} \\
\hline & Bau & 4 & & \\
\hline & Tekstur & 4 & & \\
\hline $25 \%$ & Kenampakan & 7 & \multirow{3}{*}{7} & \multirow{3}{*}{7} \\
\hline & Bau & 7 & & \\
\hline & Tekstur & 7 & & \\
\hline $50 \%$ & Kenampakan & 7 & \multirow{3}{*}{7} & \multirow{3}{*}{7} \\
\hline & Bau & 7 & & \\
\hline & Tekstur & 7 & & \\
\hline $75 \%$ & Kenampakan & 8 & \multirow{3}{*}{8} & \multirow{3}{*}{7} \\
\hline & Bau & 8 & & \\
\hline & Tekstur & 8 & & \\
\hline
\end{tabular}

Sumber: Data Primer

Penilaian sifat sensori fillet daging ayam setelah penyimpanan 6 jam dengan konsentrasi $0 \%$, $25 \%, 50 \%$ dan $75 \%$ mendapatkan rata-rata nilai akhir 4, 7, 7 dan 8 secara berurutan. Berdasarkan SNI 3924 tahun 2009 tentang mutu karkas dan daging ayam bahwa daging ayam dikatakan segar jika memiliki ciri-ciri sempurna, tebal, tidak ada memar warna, bau spesifik, elastis, kompak dan nilai minimum uji organoleptik minimal mendapatkan 7 dikatakan memenuhi syarat.

Konsentrasi $\quad 0 \% \quad$ tidak memenuhi syarat karena kondisi fillet daging ayam mengalami perubahan yaitu kenampakan yang berubah menjadi coklat dikarenakan perubahan mioglobin pembentuk pigmen pada daging 
dan akibat proses oksidasi selama proses penyimpanan (Dengen, Pratiwi. 2015). Hal ini diperkuat dalam penelitian Elvira Syamsir (2011) terjadi perubahan warna kecoklatan pada daging selama proses penyimpanan pada suhu diakarenakan mioglobin teroksidasi menjadi oksimioglobin dan teroksidasi lanjutan menghasilkan oksidadi mioglobin berwarna coklat. Adanya gelembung pada permukaan daging akibat aktivitas mikroorganisme pembusuk yang menghasilkan menghasilkan gas $\mathrm{CO}_{2}, \mathrm{H}_{2}, \mathrm{H}_{2} \mathrm{~S}$ yang terakumulasi pada permukaan fillet daging ayam (Dengen, Pratiwi. 2015). Bau anyir pada daging diakibatkan aktivitas mikroorganisme yang menghasilkan senyawa dehida akibat dari proses oksidasi Menurut Dharmawati dkk. (2016) , Perubahan fillet daging ayam menjadi mengkerut disebabkan oleh tigginya kandunga protein pada daging ayam membuat mikrooganisme cepat berekmbangbiak dan mengakibatkan terakumulasi asam laktat dan rusaknya protein miofibril selama proses penyimapanan (Lawrie, 1995). Perubahan tekstur menjadi tidak elastis pada fillet daging ayam dikarenakan proses dekomposisi dari aktivitas mikrooganisme yang mengakibatkan kerusakan struktur penyusun daging pada fillet daging ayam (Dharmawati, dkk. 2016). Pada ketiga konsentrasi (25\%, 50\% dan 75\%) hasil uji organoleptik rata-rata memenuhi syarat dengan kondisi kenampakan daging utuh, tebal sedikit ada gelembung, warna spesifik, bau spesifik dan terdapat bau tambahan (ekstrak daun kelor), elastis, agak padat dan kompak. Hal ini dikarenakan adanya kandungan antibakteri pada seperti flavanoid, alkaloid, saponin, terponoid dan steroid mampu menghambat aktivitas mikrooganisme, menyebabkan kematian mikroorganisme, dan mampu mengendalikan pertumbuhan mikrooganisme pada fillet daging ayam broiler (Anugrah, dkk. 2015).

Hasil uji organoleptik terbaik setelah perendaman 6 jam dengan variasi konsentrasi adalah konsentrasi $75 \%$. Hal ini 
dipengaruhi semakin tingg mikroorganisme semakin baik pada konsentrasi yang digunakan maka semakin tingginya kandungan antibakteri pada ekstrak daun fillet daging ayam broiler selama perendaman 6 jam Novida dwi kelor, sehingga kemampuan menghambat pertumbuhan Arizka (2017).

2. Angka Lempeng Total Fillet Daging Ayam Broiler Sesudah Perendaman 6 jam.

Pemeriksaan angka lempeng total bertujuan untuk mengetahui kualitas secara mikrobiologi fillet daging ayam setelah proses perendaman dengan ekstrak daun kelor berbagai variasi konsentrasi yang ditunjukkan pada tabel V.2 sebagai berikut :

Tabel V.2

ANGKA LEMPENG TOTAL

FILLETDAGING AYAM BROILER SESUDAH PERENDAMAN BERDASARKAN KONSENTRASI EKSTRAK DAUN KELOR

\begin{tabular}{|c|c|c|c|c|}
\hline Konsentrasi & Parameter & $\begin{array}{c}\text { Nilai } \\
\text { Rata-Rata }\end{array}$ & $\begin{array}{c}\text { Nilai Akhir } \\
\text { Organoleptik }\end{array}$ & $\begin{array}{c}\text { Persyaratan } \\
\text { Nilai } \\
\text { Minimum }\end{array}$ \\
\hline \multirow[t]{3}{*}{$0 \%$} & Kenampakan & 4 & & \\
\hline & Bau & 4 & & \\
\hline & Tekstur & 4 & 4 & 7 \\
\hline \multirow[t]{3}{*}{$25 \%$} & Kenampakan & 7 & & \\
\hline & Bau & 7 & 7 & 7 \\
\hline & Tekstur & 7 & & \\
\hline \multirow[t]{3}{*}{$50 \%$} & Kenampakan & 7 & & \\
\hline & Bau & 7 & 7 & 7 \\
\hline & Tekstur & 7 & & \\
\hline \multirow[t]{3}{*}{$75 \%$} & Kenampakan & 8 & & \\
\hline & Bau & 8 & 8 & 7 \\
\hline & Tekstur & 8 & & \\
\hline
\end{tabular}

Sumber :Data Primer

Hasil pemeriksaan laboratorium angka lempeng total pada fillet daging dengan konsentrasi $0 \%$, 25\%, 50\% dan $75 \%$ secara berurutan memperoleh hasil $3,5 \times 10^{6}$ koloni/gram , $8 \times 10^{5}$ koloni/gram, $7,7 \times 10^{4}$ koloni/gram dan 5,7 x $10^{4}$ koloni/gram. Berdasarkan SNI 7388 tahun 2009 tentang batas cemaran mikroba dalam pangan maksimal angka lempeng total pada daging ayam maksimal $1 \times 10^{6}$, sehingga dari hasil diatas angka lempeng total pada konsentrasi $0 \%$ tidak memenuhi 
syarat, sedangkan angka lempeng total pada konsentrasi $25 \%$, 50\% dan $75 \%$ memenuhi syarat, dikarenakan adanya kandungan antibakteri pada daun kelor sebagai penghambat mikroorganisme berupa senyawa metabolik sekunder diantaranya flavanoid dan alkaloid yang berikatan dengan hidrogen mengakibatkan rusaknya struktur sel dan ketidak stabilan dinding sel, serta mengganggu penyusunan peptidoglikan sel yang berfungsi membentuk struktur sel (Karlina, Ibrahim, Trimulyono. 2013), dari hasil uji pendahuluan fitokimia daun kelor salah satu kandungan senyawa saponin yang dapat menghambat pertumbuhan mikroorganisme dengan cara merusak sel sehingga terjadi penurunan permeabilitas pada membran sel mikroorganisme, jika konsentrasi yang digunakan semakin tinggi menyebabkan pecah atau lisis (Monalisa dan Dita, 2011), sehingga mengakibatkan keluarnya berbagai komponen penting dalam sel dan menyebabkan kematian sel (Dewi. K, dkk. 2016).

Senyawa steroid dalam menghambat aktivitas mikrooganisme dengan cara merusak membran plasma yang menyebabkan bocornya sitoplasma sel hingga keluar dan menyebabkan kematian sel (Putra, 2014), sedangkan untuk senyawa treponoid dalam menghambat mikroorganisme dengan cara merusakan lipidbilayer membran sel akibat gugus hidrofobik yang dimilikinya (Putra, 2014).

3. Perbedaan Konsentrasi Ekstrak Daun Kelor Terhadap Angka Lempeng Total Fillet Daging Ayam Broiler

Dilakukan Uji One Way Anova untuk mengetahui pengaruh perlakuan dengan hasil angka lempeng total yang sebelumnya telah di Uji Normalitas dan nilai $\mathrm{p}$ ( $p$ value) lebih dari 0,05 yang berarti data yang digunakan berdistribusi normal sehingga dapat dilanjutkan dengan Uji One way Anova. Hasil Uji One way Anova ditunjukkan pada tabel

V.3:

Tabel V.3

HASIL UJI ONE WAY ANOVA

\begin{tabular}{ccc}
\hline Anova & Df & Sig (p) \\
\hline Between Groups & 3 & 0,000 \\
\hline
\end{tabular}




\begin{tabular}{ccc}
\hline Whitin Groups & 32 & - \\
\hline Total & 35 & - \\
\hline
\end{tabular}

Berdasarkan uji statistik One Way Anova diperoleh nilai p 0,000 $<a$ $(0,05)$ yang menunjukkan bahwa ada perbedaan signifikkan antara konsentrasi ektrak daun kelor dengan hasil angka lempeng total terhadap fillet daging ayam konsentrasi $0 \%$, 25\%, 50\% dan $75 \%$, selanjutnya dilakukan uji lanjutan dengan menggunakan uji pada fillet daging ayam broiler dikarenakan semakin tinggi konsentrasi menunjukkan semakin tinggi penurunan angka kuman. Kandungan antibakteri yang tinggi mengakibatkan semakin besar senyawa antibakteri untuk menghambat pertumbuhan mikroorganisme Arif, Sufyan, dkk LSD yang bertujuan untuk mengetahui perbedaan konsentrasi yang paling signifikan terhadap hasil angka lempeng total.

Hasil uji lanjutan menunjukkan terjadi perbedaan siginifikan antara perbandingan konsentrasi $0 \%$, $25 \%, 50 \%$ dan $75 \%$ dengan hasil angka lempeng total berturt-turut 2800000.000, 2827777.778, dan 3031111.111, dengan nilai sig yang diperoleh $0,000<a(0,05)$, sehingga dari hasil uji tersebut dapat diketahui bahwa konsentrasi daun kelor yang dapat signifikan menurunkan angka lempeng total yaitu konsentrasi $75 \%$ dibanding dengan konsentrasi $25 \%$ dan $50 \%$.

Konsentrasi $75 \%$ yang paling signifikan dalam menghambat (2014)

\section{Kesimpulan}

1. Fillet daging ayam yang telah diuji organoleptik setelah perendaman 6 jam terdapat perubahan kualitas fisik fillet daging ayam ditandai dengan diperolehnya nilai rata-rata 4 yang berarti tidak memenuhi syarat untuk konsentrasi $0 \%, 7$ untuk konsentrasi $25 \%$ dan $50 \%$, sedangkan 8 untuk konsentrasi $75 \%$ yang berarti ketiga konsentrasi memenuhi syarat.

2. Angka lempeng total yang diperoleh pada fillet daging ayam setelah perendaman 6 jam diperoleh rata-rata keempat konsentrasi $0 \%$ 
mendapatkan $3,6 \quad$ × $10^{6}$ koloni/gram , $25 \%$ mendapatkan $8 \times 10^{5}$ koloni/gram, konsentrasi $50 \%$ $\begin{array}{llll}\text { mendapatkan } \quad 7,7 \quad \times \quad 10^{4} & \end{array}$ koloni/gram dan konsentrasi $75 \%$ mendapatkan $5,7 \times 10^{4}$ koloni/gram. Hasil penyimpanan 6 jam pada konsentrasi $0 \%$ melebihi batas menurut SNI 7388 Tahun 2009.

3. Terdapat perbedaan pemberian ekstrak daun kelor variasi konsentrasi $(0 \%, 25 \%, 50 \%$ dan $75 \%$ ) dengan angka lempeng total fillet daging ayam setealh perlakuan, dari keempat konsentrasi yang signifikan dalam menghambat pertumbuhan mikroorganisme konsentrasi $75 \%$

\section{E. Saran}

1. Bagi masyarakat terlebih untuk daerah pedesaan atau yang memiliki tanah/lahan kosong untuk menanam tumbuhan kelor karena daun kelor memiliki banyak manfaat selain dikonsumsi juga dapat menambah daya simpan daging ayam, bebek, telur, ikan atau bahan pangan yang memiliki kandungan protein tinggi jika disimpan pada suhu ruang mudah mengalami kerusakan atau penurunan kualitas.

2. Bagi peneliti lain yang ingin melanjutkan penelitian yang sejenis, untuk uji coba yang dapat dilakukan dalam mengetahui kemampuan maksimal ekstrak daun kelor terhadap kualitas fillet daging ayam dapat menggunakan variabel yang berbeda diantaranya variasi waktu ketika perendaman atau perbandingan ekstrak daun kelor dengan bahan lain yang memiliki senyawa antimikroba yang sejenis.

\section{DAFTAR PUSTAKA}

Anugrah Pura, Erdy, Kusmajadi Suradi, Lilis Suryaningsih. 2015. Pengaruh Berbagai Konsentrasi Daun Salam Terdapat Daya Awet dan Akseptabilitas Pada Karkas Ayam Broiler.

http://journals.unpad.ac.id/jurnalilmutern ak/article/download/9525/4296. 
Diakses tanggal 3 July 2018. Pukul 13.00 .

Ari. Diah, dan Dewi Windiani. 2014.

Masakan Ayam. FMEDIA. Jakarta.

Arif, Sufyan, Masdinah Ch, ms Sri Widiati.

2014. Uji Plate Count Dan

Enterobacter Daging Kambing Di

Pasar Kota Malang.

http://fapet.ub.ac.id/wp-

content/uploads/2014/03/UJI-

TOTAL-PLATE-COUNT-TPC-DAN-

ENTEROBACTER-DAGING-

KAMBING-DI-PASAR-KOTA-

MALANG.pdf. Diakses tanggal 1 Juli

2018. Pukul 08.00.

Arizka, N. 2017. Kualitas dan Daya

Simpan Ikan Kakap Merah dengan

Daun Kelor Sebagai Pengawet

Alami.

http://eprints.ums.ac.id/53758/11/

NASKAH\%20PUBLIKASI\%201\%2C5

.pdf. Diakses pada tanggal 28

Desember 2017. Pukul 13.45.

Ayutunde EO, F. O, o.t. adebayo and O.A.

Fagbenro, (2011). Toxicity of aqueous extract of Moringa oleifera seed powder to nile tilapia oreochromis niloticus (LINNE 1779), fingerlings. International Research Journal of Agricultural Science and Soil Science, 1(4):
142-150.

Terjemahan.

http://www.interesjournals.org/fullarticles/toxicity-of-aqueous-extractof-moringa-oleifera-seed-powderto-niletilapia-oreochromis-niloticuslinne-i779fingerlings.pdf. Diakses pada tanggal 9 Januari 2018. Pukul 16.20.

Dengen. Pratiwi. 2015. Perbandingan Uji Pembusukan dengan Menggunakan Metode Uji Postma, Uji Eber, Uji $\mathrm{H}_{2} \mathrm{~S}$ dan Pengujian Mikroorganisme pada Daging Babi di pasar Tradisional Sentral Makasar. Makasar.

http://repository.unhas.ac.id/bitstre am/handle/123456789/15441/PRAT IWI\%20M.R\%20DENGEN\%20\%28 \%200111\%2010\%20279\%29\%20 Kedokteran\%20Hewan.pdf?sequen $\mathrm{ce}=1$. Diakses pada tanggal 2 July 2018. Pukul 22.40.

Delfita, Rina. 2013. Evaluasi Teknik Pemotongan Ayam Ditinjau Dari Kehalalan dan Keamanan Pangan di Kabupaten Tanah Datar. Jurnal Sainstek Vol. V No. 1: 78-87, Juni 2013.

https://media.neliti.com/media/pub lications/129770-ID-evaluasiteknik-pemotongan-ayam- 
ditinjau.pdf. Diakses Tanggal 20 Juli 2018. Pukul 14.00.

Dewi. S. Rachmita. 2016. Pengaruh Lama Penyimpanan Terhadap Kualitas Daging Broiler yang Dimarinasi Jus Lengkuas. Skripsi. Jurusan Peternakan Fakultas Peternakan Universitas Halu Oleo. Kendari. http://sitedi.uho.ac.id/uploads_site di/L1A112025_sitedi_SKRIPSI\%20R ACHMITA\%20DEWI\%20S\%20TOB A\%20L1A112025.pdf. Diakses pada tanggal 15 Januari 2018. Pukul 09.10 .

Dharmawati. Siti, Achmad Jaelani, Bahrin Noor. 2016. Pengaruh Penyimpanna Daging Itik Albino Dalam Referigator Terhadap Kualitas Mikrobiologi, $\mathrm{pH}$, dan Organoleptik.

https://media.neliti.com/media/pub lications/224020-pengaruh-lamapenyimpanan-daging-itik-al.pdf. Diakses tanggal 3 July 2018. Pukul 05.00 .

Lawrie. (1995). Ilmu Daging. Penerjemah Parakkasi. UI Press, Jakarta.

Muchtadi TR, Sugiyono, Ayustaningwarno F. 2015. Ilmu Pengetahuan Bahan
Pangan. Cetakan Kelima. Alfabeta, Bandung

Putra, I Nengah encana. 2014. Potensi Ekstrak Tumbuhan Sebagai Pengawet Produk Pangan. Media Ilmiah Teknologi Pangan Vol. 1, No 1 , 81-95, 2014.https://ojs.unud.ac.id/index.p hp/pangan/article/download/13072 /8747/. 15 Januari 2018

Rohyani, Immy. E, Aryanti. Suripto. 2015. Kandungan Fitokimia Beberapa Jenis Tumbuhan Lokal yang Sering Dimanfaatkan Sebagai Bahan Baku Obat di Pulau Lombok. Jurnal Volume 1 Nomor 2 April 2015. http://biodiversitas.mipa.uns.ac.id/M /M0102/M010237.pdf. 9 November 2018. Pukul 11.00

Standar Nasional Indonesia 3924:2009 Tentang Kualitas Mutu Daging Ayam

Standar Nasional Indonesia 7388:2009 Tentang Batas Maksimum Cemaran Mikroba dalamPpangan

Syamsir.Elvira. 2011. Karateristik Mutu Daging. http://elvirasyamsir.staff.ipb.ac.id/k arateristik-muti-daging/. Diakses tanggal 4 Juni 2018. Pukul 20.00. 
